\title{
The Influence of Hug Therapy on Children's Emotional Intelligence Improvement
}

\author{
M. A. Adriansyah \& D. Rahayu \\ Universitas Mulawarman \\ Samarinda, Indonesia \\ ali.adriansyah@gmail.com
}

\begin{abstract}
The development of technology and the internet has negative impacts on the development of children's emotional intelligence. Hug therapy is one of the way which provides safety for children both physically and psychologically. The purpose of this study is to determine the effect of hug therapy on improving children's emotional intelligence. This research is a manifold preexperiment. The subjects were 15 students who had low emotional intelligence. The children's emotional intelligence scales is used as the data instrument. Data were analysed by using paired sample t-test. Result showed that hug therapy improves children's emotional intelligence based on the assessment from researcher, teachers, and parents. This means that emotional intelligence plays an important role in children's physical and psychological development.
\end{abstract}

Keywords—hug therapy; children's emotional; intelligence

\section{INTRODUCTION}

Basically, every parent wants the best future for their children. They expect that their children become successful person in the future. To achieve this, parents try to provide the best education, so that their children have good intellectual intelligence. However, intellectual intelligence itself is not enough to achieve success in life. Therefore, children should also be equipped with good emotional intelligence. According to Goleman (2004), high emotional intelligence is more important in achieving success than high intellectual intelligence as measured by standard tests of verbal and nonverbal cognitive intelligence [3]. The reason is, emotional intelligence emphasizes on the characteristics of individual personality. If someone can control anger, sadness, fear, joy well, it can help them succeed in a particular field [3].

The problem that arises today is that children begin to have difficulty in controlling their emotions. This is due to the low of children's emotional intelligence. One of the factors is the development of information technology, such as handphone, tablet PC, and even the internet. Many applications which are found by the children are not suitable as the learning sources, since mostly it contains entertainment like video games. Then, the internet makes children happier to play with gadgets, because through the internet children can find and discover new things.

In fact, children nowadays frequently use gadgets to play games than play outdoors with friends. Excessive use of gadgets or internet has a negative impact on children's development. According to Sari and Mitsalia (2016) gadgets have negative impacts on children, such as children tend to be quiet in front of strangers, children prefer to play the gadget rather than playing with friends, children sometimes imitate violent scenes in the game, and finally children ignore everything when they are in front of the gadget [12].

Furthermore, according to Anggrahini (2013), the use of gadgets in the family gives negative impacts such as children becomes difficult to communicate, do not care, and less respond when parents invite to communicate [1]. It is also in line with a research conducted by Trinika (2015) that the use of gadgets affects the psychosocial development of preschoolers (3-6 years) [14].

One action which can be done to overcome these problems is to improve the children's emotional intelligence; such as by giving hugs. Hugs are a form of nonverbal communication. Hugging is an important element in the education of a child's emotional (Bowlby, in Fossel and Astrom, 2012). Furthermore, he emphasized the importance of hugs and caresses followed by the language of love which increases the children's emotion. This is in line with Keating's (1994) point of view that by giving hugs, there will be stimulation through touching, which can improve security and safety both physically and psychologically.

According to Satir (1991) hug therapy is very beneficial; such as when it is performed four times a day, it can make individuals survive; eight times a day for physical or psychological health; and twelve times a day to keep young [13]. It shows that a simple action, such as giving a hug, creates greatly influence. Parental ignorance of the importance of giving a hug will give effect on children's development both physically and mentally. The results of Smith's (2010) study stated that the ignorance of orphanage staff in Eastern Europe 
on the importance of embracing children caused children experience serious illness including death [7].

Children who often get attention in the form of a hug from parents have different emotional intelligence with children who do not often get a hug. Psychically, hugs will make the child as a loving person and have a good confidence. It eases children to socialize and communicate with friends and the environment. Children who rarely get the attention of parents in the form of touch, cares, and hugs will make children do not have a good sense of confidence.

\section{METHOD}

\section{A. Type of research}

This is pre-experimental research which is conducted to find cause-effect relationship between treatment variable to the dependent variable. One Group Pre-test and post-test design is used to test the treatment group. [5].

\section{B. Research subject}

Research subjects were taken by purposive sampling. The consideration was that first, they were in accordance with the criteria determined by researchers; second, it is based on the recommendations from teachers who teach in class A Group 9C PAUD Al-Qalam Samarinda. The subjects of the research were 15 students who had average and or low emotional intelligence.

\section{Method of collecting data}

Methods of data collection used the children's emotional intelligence scales which have been tested for validity and reliability. A research which was conducted by Ngalifah (2010) entitled "The Influence of Classical Music on Emotional Intelligence of Children in Kindergarten Kemay Bhayangkari 06 Glondong Tirtomartani Kalasan Sleman Yogyakarta 2009/2010 School Year" got the reliability value of the children emotional intelligence scale of 0.900 [10]. It can measure the level of children's emotional intelligence continuously as a range of numbers from 1-5 which indicated the suitability of the children's emotional intelligence level.

\section{Data analysis technique}

Technique data analysis used paired sample t-test which measured two paired samples. It deals with the same subjects but they were given different treatments. Paired t-test did not need to pay attention to the variance (homogeneity) between the two groups of data, this is because the data comes from the same group.

\section{RESULT AND DISCUSSION}

The hypothesis which is tested in this research is that there is influence of hug therapy to children's emotional intelligence. Sample Paired T-Test test results were based on the three points of view; from researchers, teachers, and parents. The calculation of paired $\mathrm{T}$ test result is:

TABLE I. RESULTS SAMPLE PAIRED T-TEST ACCORDING TO RESEARCHER

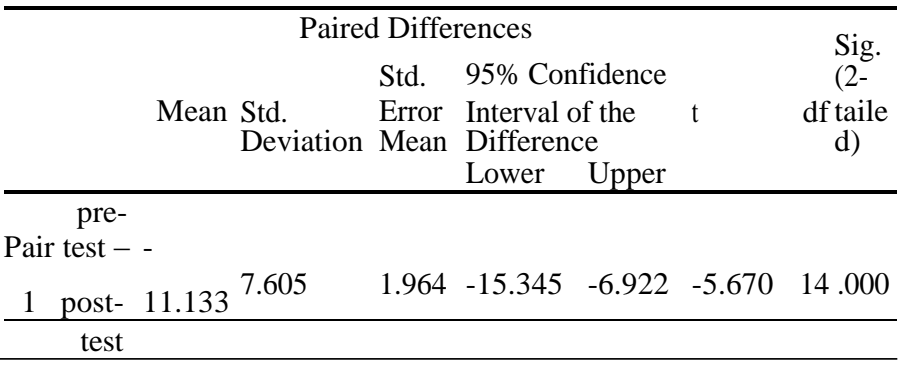

Based on table 1 above, it can be concluded that the value of $t$ counts $-5.670>t$ table -2.144 and $\mathrm{p} 0.000<0.050$. This indicates that $\mathrm{H} 1$ is accepted and $\mathrm{H} 0$ is rejected with the statement that there is an effect of hug therapy on improving children's emotional intelligence with an average of $-11,133$. According to the teacher's point of view, the result of test sample paired t-test is:

TABLE II. RESULTS SAMPLE PAIRED T-TEST ACCORDING TO TEACHER

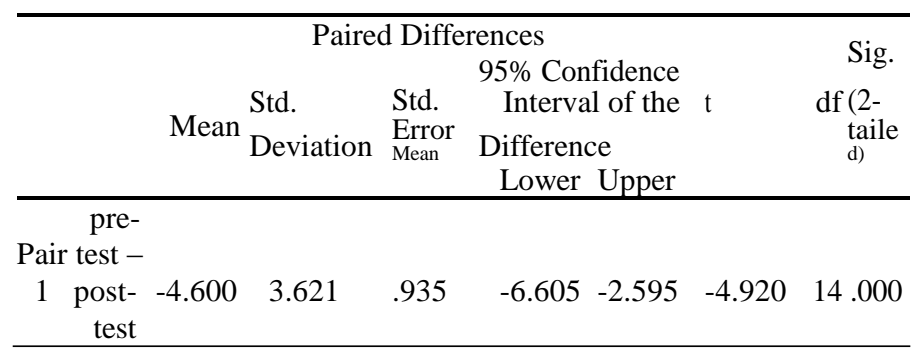

Based on table 2 above, it can be concluded that the value of $t$ arithmetic $-4.920>t$ table -2.144 and $p 0.000<0.050$. This indicates that $\mathrm{H} 1$ is accepted and $\mathrm{H} 0$ is rejected with the statement that there is an effect of hug therapy on improving children's emotional intelligence with an average of -4,600.

According to the parents' point of view, the result of test sample paired t-test is: 
TABLE III. RESULTS PAIRED T-TEST ACCORDING TO PARENTS

\begin{tabular}{|c|c|c|c|c|c|c|}
\hline & & Paire & d Diffe & rences & & \\
\hline & Mean & $\begin{array}{l}\text { Std. } \\
\text { Deviation }\end{array}$ & $\begin{array}{l}\text { Std. } \\
\text { Error } \\
\text { Mean }\end{array}$ & $\begin{array}{l}\text { 95\% Confidence } \\
\text { Interval of the } \\
\text { Difference } \\
\text { Lower Upper }\end{array}$ & $\mathrm{t}$ & $\begin{array}{l}\text { df taile } \\
\text { d) }\end{array}$ \\
\hline $\begin{array}{r}\text { pre- } \\
\text { Pair test }-\end{array}$ & & & & & & \\
\hline $\begin{array}{rr}1 \text { post- } & \text { test }\end{array}$ & -5.933 & 3.751 & .968 & $-8.010-3.856$ & -6.127 & 14.000 \\
\hline
\end{tabular}

Based on table 3 above, it can be concluded that the value of $t$ arithmetic $-6.127>t$ table -2.144 and p $0.000<0.050$. This indicates that $\mathrm{H} 1$ is accepted and $\mathrm{H} 0$ is rejected with the statement that there is an effect of hug therapy on improving children's emotional intelligence with an average of $-5,933$.

Based on the results of the calculation of paired t-test sample according to researchers, teachers, and parents above, it is evident that hug therapy affects the improvement of children's emotional intelligence. So, the proposed hypothesis is accepted, that there is the effect of hug therapy on improving children's emotional intelligence. This suggests that the treatment provided can improve the emotional intelligence of children through hug therapy.

Emotions play an important role in adjustment because it affects children as they grow into adolescence and adulthood. Anything that hinders the children's emotional development can affect the children's personal and social adjustment. Moreover, it can have an impact on physical disorders. Through teaching children to understand and express their feelings, it will affect various aspects of the development and success of life. Conversely, failing to understand and communicate feelings can lead to conflict with others. The ability to well socialize in the environment is an important key so that the children are warmly accepted in the social environment.

Cognitive intelligence affects only 20 percent of individual success, while the rest depends on emotional intelligence [9]. There are several elements of emotional intelligence found by helping children manage their emotions based on the principles of emotional intelligence, such as; children learning and being able to identify emotions, express emotions, estimate emotional levels, be able to manage emotions, able to delay emotional outbursts, able to control emotions, able to reduce emotional self-stress, and can distinguish between feelings and actions.

In this case, parents and teachers in the schools play an important role in developing children's emotional skills on Early Childhood Education optimally. One of the simple steps but has a very significant effect is through skin contact. This is because, basically human have a stimulus area from head to toe. Through contact between the skin will increase the intimacy of a relationship.
Contact between the skin can be a touch, caress, until a hug. When someone hugs each other, the hormone oxytocin will come out so that the individual will feel happier and avoid stress. According to Satir (1991) individuals basically need a hug every day to maintain physical and psychological balance [13].

The type of hug therapy used in this study is the Butterfly Hug method. Butterfly Hug provides Dual Attention Stimulation (DAS). The hugs were performed by the members of the Emotional Protection Team (EPT) who were placed around the group so they could hear the children's answers. Sometimes, the children would say their answers out loud and gave the team members the opportunity to respond to each children as needed. The thing to be sure is that the therapy participants should follow the instructions from the Emotional Protection Team (EPT) by imagining a safe or quiet place. Team members should also be vigilant and slowly approach the participants to assist in accordance with the circumstances required [2].

According to Maxfield, Melnyk, \& Hayman (2008) hug therapy has positive impacts; such as develop the cognition and physical sensation of the body, help to get closer to God, reduce violence, and stabilize life. Furthermore, according to Risjawan (2014) hug therapy provides benefits such as provide comfortable feeling, heal physical and psychological pain, provide a sense of peace, help children to grow healthy, and transform comfort from both of the embraced [11].

Treatment of hug therapy was given to the children for 3 weeks with 5 meetings. Treatment of hug therapy was only given to 15 subjects who had been selected and recommended by the home-class teacher. After treatment hug therapy was given, the children experienced a better change; such as children recognized their emotions as well as their friends, children worked with friends, children played and contributed in the group, and children learned to tolerate and helped one another. This could be seen when the silent bench competitions, where the game procedure required the children to cooperate among the group members. The children who got the seat was the winner, nevertheless, there were students who cried since they were failed. In this case, students who managed to sit the race apologized and persuaded the students not to cry anymore. Based on this activity, the children recognized a variety of emotions such as anger, sadness, and fear. All students were very enthusiastic and emulate very well.

Based on the above results, it is concluded that hug therapy provides changes and improves the emotional intelligence of children. That is, if hug therapy is given to children on a regular basis, children will be able to learn and develop emotional intelligence as well as stock development in the future. 


\section{CONCLUSION}

Based on the results of research that has been done then it can be concluded as follows:

1. According to the researcher, the subjects who were given the hug therapy experienced emotional intelligence with the value of $t$ count $-5.670>t$ table $2.144, \mathrm{p} 0.000<0.050$ and mean -11.133 .

2. According to the teacher, the subjects who were given hug therapy experienced emotional intelligence with a value of t count $-4.920>\mathrm{t}$ table -2.144 , p $0.000<0.050$ and mean 4.600 .

3. According to the parents, the subjects who were given hug Therapy experienced emotional intelligence with a value of t count $-6.127>$ t table 2.144, p $0.000<0.050$ and mean 5.933 .

\section{REFERENCES}

[1] S. A. Anggrahini, Dinamika Komunikasi Keluarga Pengguna Gadget, Naskah Publikasi, Fakultas Ilmu Sosial dan Humaniora Universitas Islam Negeri Sunan Kalijaga, Yogyakarta, 2013.

[2] L. Artigas, I. Jarero, M. Mauer, T. López Cano, and N. Alcalá, EMDR and Traumatic Stress after Natural Disasters: Integrative Treatment Protocol and the Butterfly Hug, Poster presented at the EMDRIA Conference, Toronto, Ontario, Canada, 2000.

[3] D. Goleman, Kecerdasan Emosional: Mengapa EI Lebih Penting Daripada IQ, Terjemahan oleh T. Hermaya. 2004. PT. Gramedia, Jakarta, 2004.

[4] K. Keating, The Hug The Therapy Hug Therapy, Hazelden Foundation, Minessota, 1994.

[5] Latipun. Psikologi Eksperimen (Edisi Kedua), 2008.

[6] UMM Press, Malang.

[7] L. S. Smith, Keeping the Promise: The Criti- cal Need for PostAdoption Services to Enable Children and Families to Succeed, Evan B.Donaldson Adoption Institute, New York, 2010.

[8] L. Maxfield, W.T. Melnyk, and C.A.G. Hayman, "A working memory explanation for the ef- fects of eye movements in EMDR," Journal of EMDR Practice and Research, vol. 2, no. 4, pp. 247-261, 2008.

[9] S. Mulyadi, Membantu Anak Mengelola Amarahnya. Erlangga: Surabaya, 2004.

[10] S. Ngalifah, Pengaruh Musik Klasik terhadap Kecerdasan Emosional Anak di TK Kemala Bha-yangkari 06 Glondong Tirtomartani Kalasan Sleman Yogyakarta Tabun Ajaran 2009/2010, Naskah Publikasi. Fakultas Tarbiyah Universitas Islam Negeri Sunan Kalijaga, Yogyakarta, 2010.

[11] H. Risjawan, Manfaat Pelukan untuk Kesehatan, PT. Gramedia Pustaka Utama, Jakarta, 2014.

[12] T. P. Sari, and A. A Mitsalia, "Pengaruh Penggunaan Gadget Terhadap Personal Sosial Anak Usia Pra Sekolah Di Tkit Al Muk- min," Jurnal Profesi, vol. 13, No. 2, 2016.

[13] V. Satir, The Satir Model: Family Therapy and Beyond. Science and Behavior Books, Palo Alto, 1991.

[14] Y. Trinika, Pengaruh Penggunaan Gadget Terhadap Perkembangan Psikososial Anak Usia Prasekolah (3- 6 Tahun) Di TK Swasta Kristen Immanuel Tahun Ajaran 2014-2015, Naskah Publikasi. Fakultas Kedokteran Universitas Tan-jungpura Pontianak, 2015.

[15] E.H. Grotberg, A guide to promoting resilience in children: Strengthening the human spirit. The Hague, The Netherlands: Bernard van leer foundation, 1995. 